\title{
GIS Based Land Capability Classification of a Watershed for Land and Water Resource Management
}

\author{
Purnima Mishra ${ }^{1 *}$ and R.R. Babu ${ }^{2}$ \\ ${ }^{1}$ Department of Horticulture Engineering, College of Horticulture, SKLTSHU, \\ Rajendranagar, Hyderabad - 500030, India \\ ${ }^{2}$ National Bank for Agriculture and Rural Development, Bandra Kurla Complex, Bandra \\ (East), Mumbai - 400051, India \\ *Corresponding author
}

\section{A B S T R A C T}

With a view to suggest suitable land and water resource management measures in a degraded micro-watershed, land capability class map of a micro-watershed, falling in upper catchment of Dwarakeswar river, Chotanagpur plateau was prepared in Geographic Information System (GIS) environment by generating and integrating various thematic maps. The generated and integrated thematic maps of watershed using GIS included land use/cover, soil slope, drainage network, soil depth, soil texture and erosion status, etc. Based on the integrated land capability class map of the watershed, four land forms viz., upland -class VI, midland -class IV/III, low land - class III and valley Bohal-class II were found. $78 \%$ of total area of watershed was under class III, which is mostly mono-cropped agriculture land, while $15 \%$ of the area of watershed, which is wasteland was found be under class IV. The area under land class II comprised of $4 \%$ of total area of watershed in which double cropping is practiced. The land class of uplands was found to be VI, which comprised of $3 \%$ of total area of watershed. Finally, based on the land class map, a package of soil and water conservation measures were suggested that can be taken up for land and water resource management with local people active participation.

\section{Introduction}

Rainfed areas constitute about 52\% of net cultivated area and contribute to more than $40 \%$ of food production of the country. They are home to small and marginal farmers, poor and vulnerable sections of the society. The rainfed areas are characterized by severe land degradation and low productivity. Further, of late, the adverse effects of climate change are posing serious threat to sustainability of rainfed farming. Watershed development programmes in rainfed areas aim at conservation and regeneration of natural resources and help in protection of soil, moisture and vegetation, thereby facilitate livelihood of the people depending on these vital resources. In any watershed development programme, the first step is the establishment of land capability class, based on which the 
problems and potentials can be known and the treatments and alternative land use practices are planned.

In order to plan suitable soil and water conservation measures, after delineation of watershed on topo sheet using the present land use map along with drainage network, plot wise/survey number wise land class of the watershed is to be established. After establishing the land class, suitable soil and water conservation measures with their design details along with proposed land use map can be prepared. With the advent of remote sensing and Geographic Information System (GIS), generation of required thematic layers, their integration and spatial analysis have become easy and convenient. Several researchers (Suryawanshi et al., 2005, Mishra et al., 2006, Mishra and Babu, 2009, Mary Silpa and Nowshaja, 2016) demonstrated the use of remote sensing and GIS in establishing land use/cover and preparation of land capability class maps, etc., for different watersheds/study areas. In the present study, an attempt is made to prepare an integrated Land Capability Class (LCC) map, identify and suggest suitable soil and water conservation measures based on land class for effective land water resource management in a watershed.

Bhalukanala, an agricultural micro-watershed falling in the upper catchment of Dwarakeswar River, eastern part of India was selected for the study. The watershed is located at $23^{0} 11^{\prime} \& 23^{0} 14^{\prime} \mathrm{N}$ latitude and $86^{0} 54^{\prime} \& 86^{0} 56^{\prime}$ E longitude. The total geographical area of the watershed is 1006.40 ha. The climate is sub-tropical humid with average annual rainfall of $1340 \mathrm{~mm}$, of which more than $80 \%$ is received during South-West (June-October) monsoon period. The mean maximum and minimum temperatures are about $38^{\circ} \mathrm{C}$ and $10^{\circ} \mathrm{C}$, respectively in the selected watershed.

\section{Materials and Methods}

The toposheet of Survey of India (73I/16/NE) covering the entire watershed was rectified and projected. Contours and stream network were digitized and the Digital Elevation Model (DEM) was generated and thus delineation of watershed was completed. The delineated watershed was separated from the main image and its vector feature was created. The land use/cover map of watershed was generated by Maximum Supervised Classification of the remote sensing (IRS P6 LISS III digital image (path 106 and row 55)) imagery coupled with field survey. The land use/cover map of Bhalukanala watershed was overlaid on the slope map and the physiogrpahy map was thus derived. This physiogrpahy map was taken as the base map and the field data pertaining to soil depth, texture and erosion status were collected for each mapping unit. Subsequently, thematic maps viz., Soil texture, Soil depth, Soil Slope, Erosion status and Drainage map were generated. All these thematic maps are superimposed on base map in the GIS platform. Looking at the rating table (Tideman, 1996), the land class of each mapping unit has been finalized and thus an integrated LCC map of the watershed wasprepared using the GIS platform. Thereafter, land and water resource management plan was prepared in the form of package of soil and water conservation measures suiting to estimated land class.

\section{Results and Discussion}

The generated and integrated thematic maps of watershed using GIS including land use/cover, soil slope, drainage network, soil depth, soil texture and erosion status, etc., were used in preparing LCC map of Bhalukanala watershed. The final LCC map of Bhalukanala watershed is given in Fig. 1. The area under different land classes is 
presented in Fig. 2. The land forms/classification in Bhalukanala watershed revealed typical characteristic resembling to Chotanagpur plateau. The land forms/class in this watershed were classified into four groups upland-class VI, midland -class IV/III, low land - class III and valley-class II, based on the topography and soil characteristics. The land class wise summary of recommended soil and water conservation measures and alternate land use practices for effective land and water resource management are given in Table 1. The presented results in Fig.1, Fig. 2 and Table 1 are discussed below:

The analysis of area under different land classes in Bhalukanala micro-watershed (Fig. 1) indicated that about $78 \%$ of total area of watershed falls under land class III, which is mostly mono-cropped Agriculture land.
Repairs to existing field bunds and construction of on farm reservoir or water harvesting tanks will help in in situ retention of rainfall and maintaining soil moisture for longer period. These measures will also facilitate farmers in growing short duration second crop like chickpea and help in improving the income of farmers. As the soils of laterite zone are poor in organic matter content application of organic and green manures to soil will help in enhancing its content in the soil thereby improving the moisture holding capacity of the soil. The area under land class II (which is $4 \%$ of total area of watershed) also needs application of organic manures and repairs to existing field bunds and construction of water harvesting tanks (large in size) at appropriate places particularly in the valley region. Crop rotation (Paddy-pulses/vegetables) was suggested as land use.

Table.1 Suggested soil and water conservation measures and alternative land use practices for Bhalukanala watershed, Bankura

\begin{tabular}{|c|c|c|c|}
\hline S.No. & $\begin{array}{l}\text { Land } \\
\text { class }\end{array}$ & $\begin{array}{l}\text { Suggested soil and water } \\
\text { conservation Measures }\end{array}$ & $\begin{array}{l}\text { Suggested alternative } \\
\text { land use practices }\end{array}$ \\
\hline 1 & $\mathrm{II}_{\mathrm{s}}$ & $\begin{array}{l}\text { i) Repairs to existing Field Bunds. } \\
\text { ii) Application o organic and green } \\
\text { manures }\end{array}$ & $\begin{array}{l}\text { Double cropping (Paddy- } \\
\text { Pulses/vegetables rotation }\end{array}$ \\
\hline 2 & $\mathrm{III}_{\mathrm{s}}$ & $\begin{array}{l}\text { i) Repairs to existing Field Bunds } \\
\text { and small }(5 \%) \text { rain water } \\
\text { harvesting tanks in filed plots } \\
\text { ii) Application of organic and } \\
\text { green manures and mulching }\end{array}$ & $\begin{array}{l}\text { Double cropping (Paddy- } \\
\text { Pulses/oil seeds/vegetables } \\
\text { rotation) }\end{array}$ \\
\hline 3 & $\mathrm{IV}_{\mathrm{s}}$ & $\begin{array}{l}\text { i) Contour /Graded Bunding and } \\
\text { small gully plugs with suitable } \\
\text { grass cover/vegetative barriers } \\
\text { ii) Application of organic and } \\
\text { green manures and mulching. }\end{array}$ & Agro-Horticulture \\
\hline 4 & $\mathrm{VI}_{\mathrm{s}}$ & $\begin{array}{l}\text { Staggered Contour } \\
\left.\text { Trenches/Negarian ( } 30^{\prime} \times 40^{\prime}\right) \text { plots } \\
\text { with seepage pits and gully plugs }\end{array}$ & $\begin{array}{l}\text { Afforestation/Pasture } \\
\text { development. Ban on free } \\
\text { grazing and tree felling }\end{array}$ \\
\hline
\end{tabular}


Fig.1 Land capability class map of Bhalukanala watershed

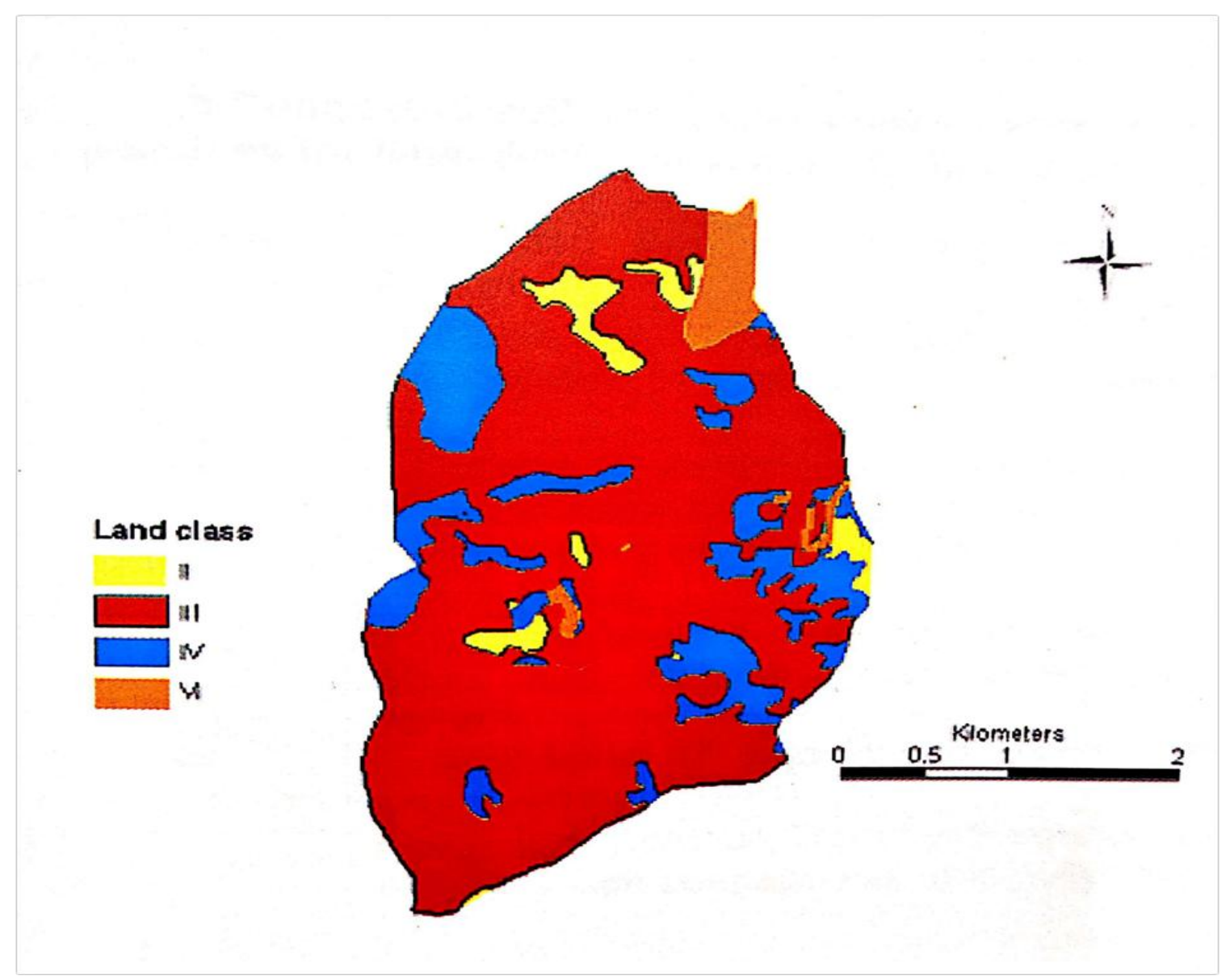

Fig.2 Area under different land classes

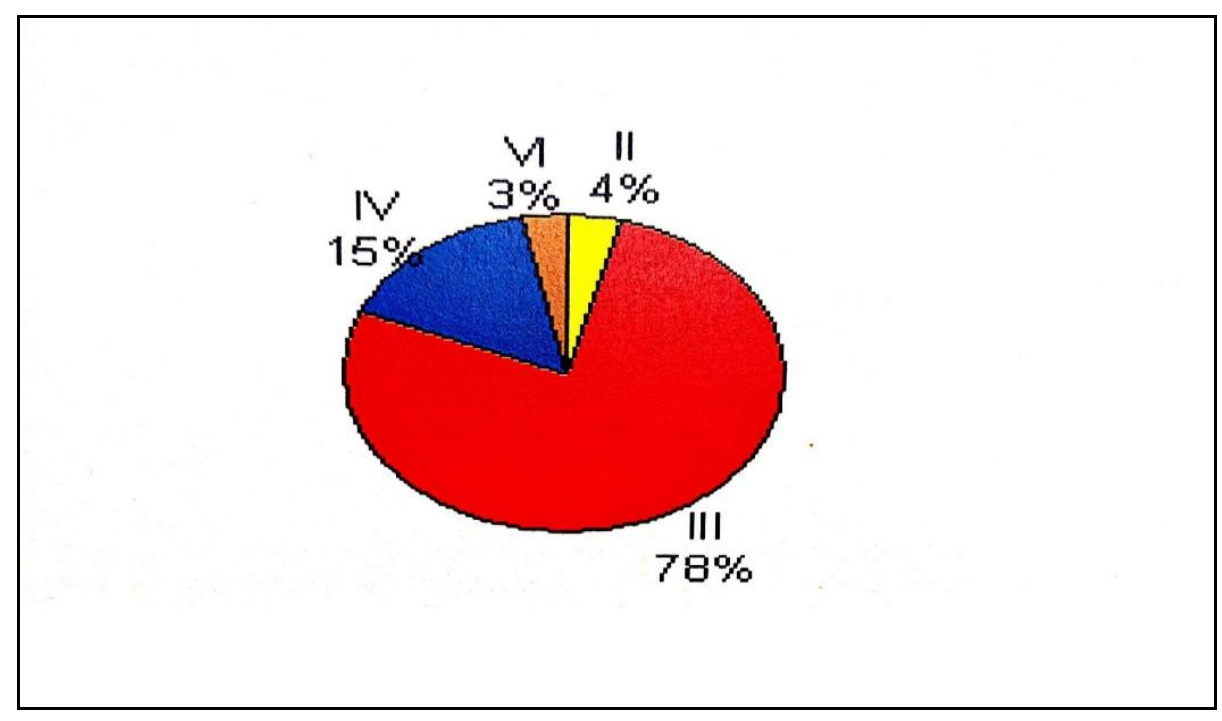


Most of the area under wasteland category was found to be under land class IV comprising of $15 \%$ of total area of Bhalukanala micro-watershed (Fig.1). The suitable measure for this class of land is contour/graded bunding. Alternatively, the Negarian plots with seepage tanks could also be practiced for improving the soil moisture and controlling further soil erosion. Horticulture development is an ideal alternative land use practice for the area under land class IV. The land class of uplands was found to be VI, which comprised of $3 \%$ of total area of watershed. The uplands possessed very shallow soil depth with light textured soil on the surface. These are fallow lands without the cover of vegetation and require immediate attention for treatment. The suitable treatment could be Staggered Contour Trenches/Negarian plots with seepage pits. The suggested alternative land use for the area under land class VI is Afforestation/Pasture development.

The final LCC map needs to be overlaid on digitized cadastral/village maps to come out with plot/survey number wise land class. The suggested soil and water conservation measures (Table 1) and alternate land use practices need to be discussed with land owners and watershed community and finalized for implementation for effective land and water resource management leading to livelihood security of the inhabitants.

In conclusion, the developed LCC map and suggested package of soil and water conservation measures of Bhalukanala watershed, on implementation would help in arresting soil erosion, insitu conservation of rainfall, maintaining soil moisture for longer period and regeneration of natural resource base. This in turn stabilizes farming and meet the food, fodder and timber/fuel wood requirement of people in a sustainable manner in Bhalukanala watershed.

\section{References}

Mary Silpa, T.J. and Nowshaja, P.T. 2016. Land Capability Classification of Ollukara block panchayat using GIS. Procedia Technology 24(2016): 303308.

Mishra, P., Mazumdar, A., Roy, D. and Ravi Babu, R. 2006. Land capability class map of an agricultural micro-watershed using GIS. Environment and Ecology, 24(3): 485-489

Mishra, P. and Ravi Babu, R. 2009. Simulation of storm sediment yield from an agricultural watershed using remote sensing, GIS and MUSLE. Journal of Soil and Water Conservation, 8(3): 12-21.

Suryawanshi, S.L., Pathak, S.V., Pali, A.K and Das, S.N. 2005. Application of remote sensing and Geographic Information System in Land Capability Classification. Hydrology and watershed management, Himanshu publications, Udaipur. In: Kumar, V, Singh, PK and Purohit, R.C. (ed). pp: 210-223.

\section{How to cite this article:}

Purnima Mishra and Babu, R.R. 2021. GIS Based Land Capability Classification of a Watershed for Land and Water Resource Management. Int.J.Curr.Microbiol.App.Sci. 10(01): 1268-1272. doi: https://doi.org/10.20546/ijcmas.2021.1001.150 